いて統計学的な検討を加えることとした。ての際，骨の 成熟度については，大原が第36回の衛生学会で発表した 如く前腕骨・手根骨・基節などの総評点法が妥当性のあ る評尺として用いられる。しかしその後の研究によって 軽便法として，中学生女子においては指骨とくに第 4 指 の基節，男子においては第 3 指の発育度のみによって評 価できるととがわかった。

私たちは今回はてれらを標示として関係する作用因子 等との相関や分析を試みた。他方，栄養摄取状況につい ては，別途，大山が発表するでとく食品の計量法と記録 法によった。運動量はエネルギー代謝率（RMR）によ り，睡眠・休蒦・娱楽・学習なぞの実態は文部省方式に よる生活時間調查法によった。骨の成熟は過去における 長期間の諸要因の蓄積の総和によるものであるから，現 時点にわける生活の策態とは必ずしも密接に值結するも のではないが，地方農村等における生活の因習はを机ほ ど急変するものとも考光られない。よって現在の生活の 実態と発育の現状とを関連づけて推測を行なうことは， 危険性を伴うととを承知の上で妥当性を考慮するととも 可能である。

以上の観点仙よって作用因子の発育に及ぽす比重を求 めると栄養が最大の因子であり，文化刺戟などは比較的 小さな作用しか示さないととが推論される。

\section{9 骨成熟度の判定に関する研究}

$\begin{array}{lr}\text { O吉岡文雄 } & \text { (京都女子大) } \\ \text { 川烟愛義, 松浦義行, 八木 保 (京大) } \\ \text { 大原純吉 } \\ \text { (京都産業大) }\end{array}$

我が国の学徒の発育の acceleration は，諸種の観点 より検討されている。私達は，乙れを骨の成熟度の促進 から検討しょうとして，中学 2 年生男女 714名につい $\tau, X$ 線学的観察を行なった。また生活時間即ち, 運動, 休養，睡眠，学習，㛎楽等の実態を調べると共に，笑養 の摂取，生活環境の椂相についても調査し，更に文化刺 戟としての， television， radio，週刊誌その他につい ても，質問紙法によって調へ，またてれらの諸要因が， 発育の促進に如何なる比重をもって貢献しているかを追 求するとととした。

先ず骨の成熟度，骨年令の発育度は，足零，手根骨等 によって評価されているが，私達は，前腕骨，手根骨， 中手骨, 指骨等について撮影し，從来提唱されているグ リューリッヒ，並びに井上，中沢氏等の総骨点評を参考 として，更に之を簡易化するととの可能性について吟昧
Uた。

（1）総骨点評に対する相関係数を各骨の分類別に見る と, 男子は指骨, 中手骨, 手根骨, 前腕骨, 女子は指骨, 中手骨，前腕骨，手根冎の順位で前者が高くなった。

（2）指骨と各節の相関係数を見ると，男女共に基節が 誛も高く，ついで中節，末節の順位となる。

（3）中手骨，指骨の基節，中節，末節の合計点評を， 各指別に総骨点評との相関係数を, 順位変換して, 再び 相関係数で比較して見ると，男子は第 3 指，女子は第 4 指が，第1位であった。

（4）以上によって，第 2 の発育促進期に於いては，骨 の成熟度を見るのに，男子は第 3 指，女子は第 4 指をも って評価するととができる。

（5）骨の成熟䎲貢献する栄養，運動，環境，文化刺戟 等の諸要因は，作用の樣相が複雑であるが，それ等を簡 易化して比較し，その本態についても略説する。

\section{0 未熟児の小・中学校期における体型評価}

相沢 龍, ○後藤ヨシ子, 川副正昭

（長崎大公衛）

自的：炤和 30 年以来行なってきた未熟览の発育に関す る Follow-up study において，来熟児群は成熟归群に くらべ,比体重及び Wetzel発育指数でみた充実的発育で 㸓りが指摘され，しかも，比座高の未成差の推移からみ て，中学校期での身長の劣りは，主に下肢長の発育面の 沙りによるものと考兄られた。そてで未熟罗の形態的発 会良否判定の試みとして，身体指数做の組み合せによる 涽標を用い，小・中学校期における体型判定を検討して 及た。

対象：未熟児 150 名, 成熟児 302 名, 計 452 名。学年 によって繼続研究中転校並びに測定値不足のため若干人 数に变動がある。

方法 : 比体重，比下肢長それぞれ未成混合性別に平均 值土標準偏差で上中下に 3 階級区分し，両指数值ともに 平均值範囲にあるものを中とし体型普通，ともに上を体 型良,下を体型不良, 上下組み合せのものを体型不釣合と 判定。一方 Wetzel 指数値による stocky, medium, thin の3区分階級を比下肢長と組み合せ同様の判定で 各個人別化評価し，学年毎の比較及び小・中学校全期の 総合評価も行なった。

成績ならびに結論：比体重と比下肢長の組み合せから 行なった体型評価の結果では，小・中学校全学年におい て未成差が著しく，常に未熟览群体体型不良が多く，さ らに小・中学校 8 年間（小 1 は下肢長測定なし）の総合 